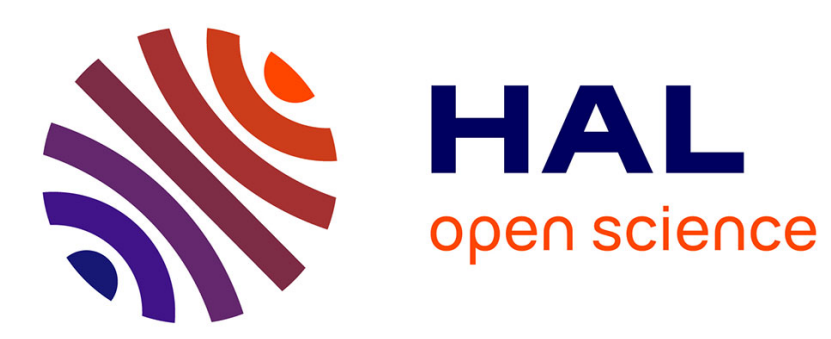

\title{
Is the electrocatalytic epoxidation of stilbene isomers using manganese (III) tetradentate Schiff bases complexes stereoselective?
}

\author{
Ali Ourari, Lotfi Baameur, Mustayeen A Khan, Gilles Bouet
}

\section{To cite this version:}

Ali Ourari, Lotfi Baameur, Mustayeen A Khan, Gilles Bouet. Is the electrocatalytic epoxidation of stilbene isomers using manganese (III) tetradentate Schiff bases complexes stereoselective?. Electrochemistry Communications, 2008, 10 (11), pp.1736-1739. 10.1016/j.elecom.2008.08.053 . hal-03243907

\section{HAL Id: hal-03243907 \\ https://univ-angers.hal.science/hal-03243907}

Submitted on 31 May 2021

HAL is a multi-disciplinary open access archive for the deposit and dissemination of scientific research documents, whether they are published or not. The documents may come from teaching and research institutions in France or abroad, or from public or private research centers.
L'archive ouverte pluridisciplinaire HAL, est destinée au dépôt et à la diffusion de documents scientifiques de niveau recherche, publiés ou non, émanant des établissements d'enseignement et de recherche français ou étrangers, des laboratoires publics ou privés. 
Provided for non-commercial research and education use. Not for reproduction, distribution or commercial use.

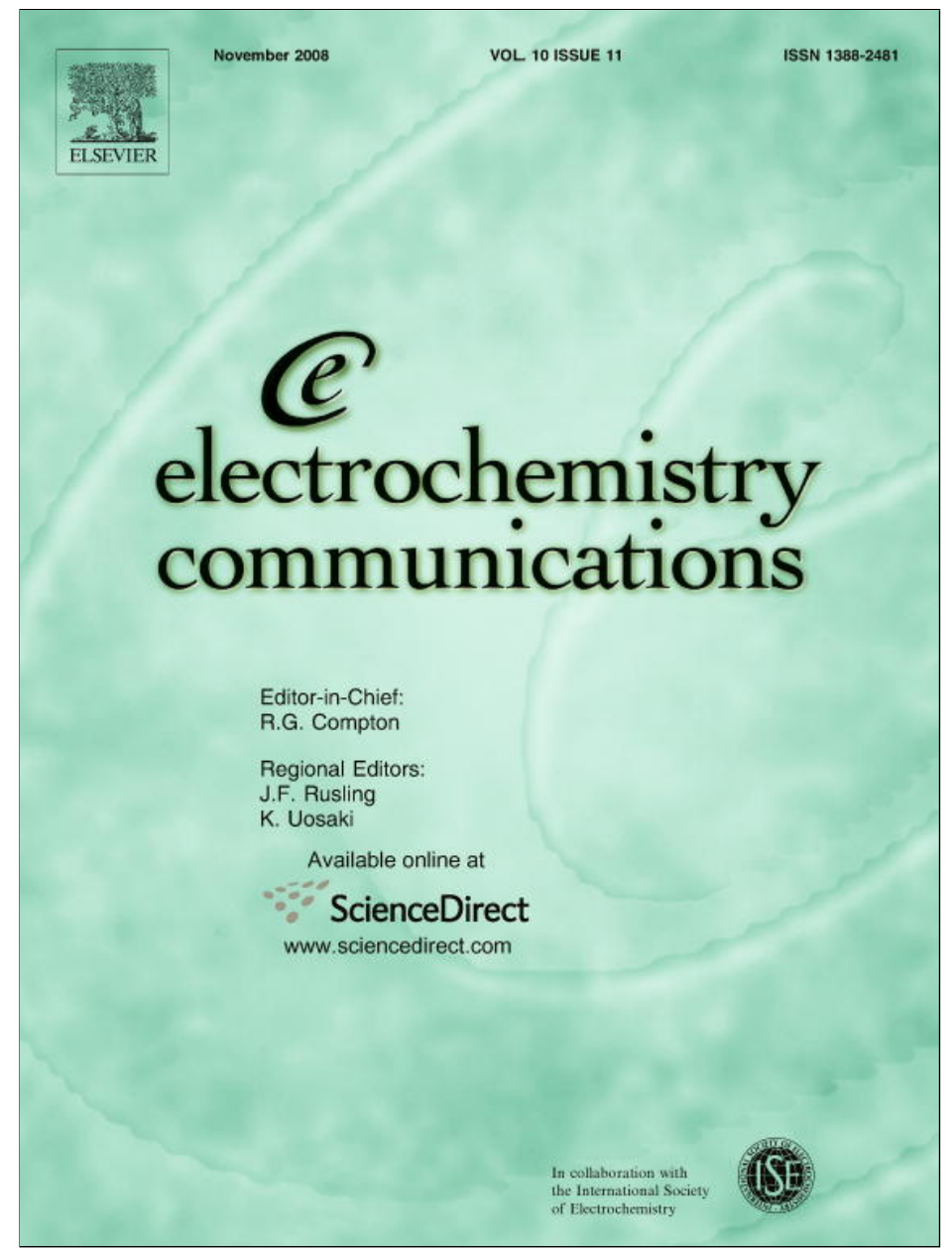

This article appeared in a journal published by Elsevier. The attached copy is furnished to the author for internal non-commercial research and education use, including for instruction at the authors institution and sharing with colleagues.

Other uses, including reproduction and distribution, or selling or licensing copies, or posting to personal, institutional or third party websites are prohibited.

In most cases authors are permitted to post their version of the article (e.g. in Word or Tex form) to their personal website or institutional repository. Authors requiring further information regarding Elsevier's archiving and manuscript policies are encouraged to visit:

http://www.elsevier.com/copyright 


\title{
Is the electrocatalytic epoxidation of stilbene isomers using manganese (III) tetradentate Schiff bases complexes stereoselective?
}

\author{
Ali Ourari ${ }^{\mathrm{a}}$, Lotfi Baameur ${ }^{\mathrm{a}, \mathrm{b}}$, Mustayeen A. Khan ${ }^{\mathrm{b}}$, Gilles Bouet ${ }^{\mathrm{b}, *}$ \\ a Laboratoire d'Electrochimie, d'Ingénierie Moléculaire et de Catalyse Redox (LEIMCR), Faculté des Sciences de l'Ingénieur, Université Ferhat Abbas, DZ-19000 Sétif, Algeria \\ ${ }^{b}$ Laboratoire SONAS, EA 921, IFR149 QUASAV, Faculté de Pharmacie, 16 Boulevard Daviers, F-49045 Angers Cedex 01, France
}

\section{A R T I C L E I N F O}

\section{Article history:}

Received 2 July 2008

Received in revised form 25 August 2008

Accepted 28 August 2008

Available online 12 September 2008

\section{Keywords:}

Electrocatalysis

Manganese complexes

Olefins epoxidation

Molecular oxygen

Biomimetic catalysis

\begin{abstract}
A B S T R A C T
Three manganese (III) complexes were obtained with $\mathrm{H}_{2}$ Salen derivatives and used as catalysts in the epoxidation reactions of $E$ - and Z-stilbene isomers. The preparative electrolyses were carried out at $25^{\circ} \mathrm{C}$ in acetonitrile solution containing $0.1 \mathrm{M}$ TBAP, $10^{-3} \mathrm{M}$ complex, $10^{-2} \mathrm{M}$ 2-methylimidazole and $0.1 \mathrm{M}$ benzoic anhydride plus stilbene as substrate. Our results showed clearly that $E$-stilbene was totally converted to $Z$-stilbene oxide whereas $Z$-stilbene leads to a mixture in which the benzaldehyde was the major by-product. In our experimental conditions, the turnovers recorded for different experiments were located in the 3.7-6.6 range.
\end{abstract}

(c) 2008 Elsevier B.V. All rights reserved.

\section{Introduction}

Epoxidation with synthetic metal Schiff bases complexes and porphyrins models of cytochrome P-450 is a topic of continuing research interest. According to Bedioui et al. [1], the high valent oxo-metal $\left([\mathrm{P}-450-\mathrm{Fe}(\mathrm{V})=\mathrm{O}]^{+}\right)$which is suggested to be the active olefin oxidant, was generated using various ways: (i) direct oxygen atom transfer agents such as $\mathrm{PhIO}, \mathrm{H}_{2} \mathrm{O}_{2}, \mathrm{ClO}^{-}$, $\mathrm{ROOH}, \mathrm{KHSO}_{5}$, $\mathrm{ClO}_{2}{ }^{-}, \mathrm{RCO}_{3} \mathrm{H}$ and $\mathrm{R}_{3} \mathrm{NO}$; (ii) reduced dioxygen species and with dioxygen plus reductant. The second pathway is especially interesting from the viewpoints of biomimesis and practical utilisation of molecular oxygen. The electroassisted formation of the oxo species requires the enzyme model plus molecular oxygen, an activator and one or two axial ligands. The use of electrochemical control techniques combined with metal complex catalysts can supply reducing equivalents in a more easily adjustable manner than in the case of a reaction mixture containing chemical reductants [1-3].

$\mathrm{H}_{2}$ Salen, as a ligand (Fig. 1), has the characteristics to be readily subject to systematic modification of its electronic and steric properties. Mainly, the substituents $\mathrm{X}$ in para positions modify the redox properties of metal-salen complexes. In addition, their steric properties seemed to depend on the bridge between the symmetrical moieties of the molecule [4].

\footnotetext{
* Corresponding author. Tel.: +33 2412266 00; fax: +33 241226634 .

E-mail address: gilles.bouet@univ-angers.fr (G. Bouet).
}

The mechanism of the epoxidation reaction by $\mathrm{Mn}(\mathrm{III})-$ salen complexes is analogous to the cytochrome P-450 catalytic system. The more important steps are the binding of $\mathrm{O}_{2}$ after the electrochemical reduction of the $\mathrm{Mn}(\mathrm{III})$-peroxo species by a one electron process, followed by the transfer of a second electron to give a species described as a Mn(III)-peroxo complex (Fig. 2). The three steps involved in the $\mathrm{O}_{2}$ activation process represent a typical ECE reaction sequence. A key step in this case is the subsequent cleavage of the $\mathrm{O}-\mathrm{O}$ bond by an electrophilic activator like benzoic anhydride.

The reactivity of high valent manganese compounds with olefins has been extensively studied and was typically generated [5]. We report here the "unusual" reactivity of $\mathrm{Mn}(\mathrm{III})$-salen complexes. The oxidation of $E$-stilbene lead only to the $Z$-stilbene oxide showing a complete configuration inversion. In addition, the oxidation of $Z$-stilbene gave mainly $Z$-stilbene oxide with traces of $E$-stilbene oxide. As far as we know, this behaviour has never been reported in literature.

\section{Experimental}

\subsection{Chemicals}

Salicylaldehyde, 5-chlorosalicylaldehyde, 5-methoxysalicyaldehyde, 1,2-diaminoethane, $\mathrm{Mn}\left(\mathrm{C}_{2} \mathrm{H}_{3} \mathrm{O}_{2}\right) \cdot 4 \mathrm{H}_{2} \mathrm{O}, \mathrm{MnCl}_{2} \cdot 4 \mathrm{H}_{2} \mathrm{O}$, tetraethylammonium perchlorate (TEAP), $Z$-stilbene, $E$-stilbene, $Z$-stilbene oxide, $E$-stilbene oxide, benzaldehyde, benzoic anhydride, 2-methyl-imidazole (2-MeI), anhydrous EtOH and $\mathrm{CH}_{3} \mathrm{CN}$ were purchased from Alfa Aesar and used as received. 
a

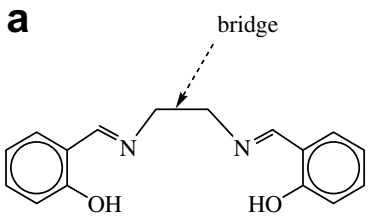

b

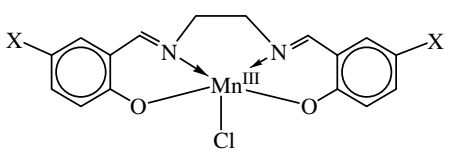

Fig. 1. (a) $\mathrm{H}_{2}$ salen, (b) $\mathrm{Mn}(\mathrm{III})$-salen derivatives complexes with $\mathrm{X}=\mathrm{Cl}$ or $\mathrm{CH}_{3} \mathrm{O}$.
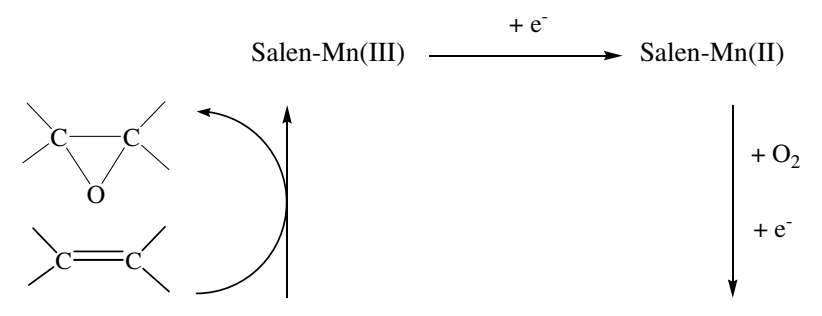

$\underset{\mathrm{C}_{6} \mathrm{H}_{5} \mathrm{COO}^{-}}{[\text {Salen-Mn(V)=O}]^{+}} \overbrace{\left(\mathrm{C}_{6} \mathrm{H}_{5} \mathrm{CO}\right)_{2} \mathrm{O}}^{[\text {Salen-Mn(III)-O }}$

Fig. 2. Proposed scheme for the electrocatalytic epoxidation of olefins.

\subsection{Synthesis of ligands and complexes}

The ligands and their corresponding complexes were prepared, purified and characterised according to literature [6,7].

\subsection{Physical measurements}

The cyclic voltammograms (CV) were obtained in a single compartment cell $(5 \mathrm{~mL})$ at $25^{\circ} \mathrm{C}$. A Pt wire and sodium chloride saturated calomel electrode (SCE) were the auxiliary and reference electrodes respectively. The solvent was acetonitrile with TEAP as supporting electrolyte $\left(10^{-1} \mathrm{M}\right)$. Controlled potential electrolyses were made with a TACUSSEL PRT (40-1X) potensiostat, an integrator IG-LN, a Kipp \& Zonen X-Y Recorder B.D 90. The electrocatalytic epoxidation experiments were performed using carbon Lorraine flag $(A=10 \mathrm{~mm} \times 0.8 \mathrm{~mm} \times 0.5 \mathrm{~mm})$ as working electrode. The reference electrode (SCE) was separated from the working solution by a fine-porosity frit, the Pt electrode, was placed directly in the working solution. Both an atmosphere of purified $\mathrm{O}_{2}$ and slowly stirring were maintained over the reaction mixture which contained $\mathrm{Mn}(\mathrm{III})$-salen complex $\left(10^{-3} \mathrm{M}\right), 2$ MeI $\left(10^{-2} \mathrm{M}\right)$ and $10^{-1} \mathrm{M}$ of each olefin and benzoic anhydride. The electrocatalytic process was followed until the current decayed to $10 \%$ to $5 \%$ of its initial value. Products were analysed using HPLC with a Kromasil inverted phase analytic column $\left(C_{18}, 250 \times 4.6 \mathrm{~mm}\right)$, Hewlett-Packard 1100 series with an UV detector.

\subsection{HPLC analysis}

After removing the solvent under reduced pressure, anhydrous ether was added to the resulting brown product leading to the precipitation of a solid residue which was removed. The resulting solution is concentrated until precipitation. Finally, the resulting solid was dissolved in $5 \mathrm{~mL} \mathrm{MeOH}$ and $20 \mu \mathrm{L}$ were injected (elution solvent: $\mathrm{MeOH} / \mathrm{H}_{2} \mathrm{O}(85 / 15, \% \mathrm{~V} / \mathrm{V})$, flow rate: $1 \mathrm{~mL} \cdot \mathrm{min}^{-1}$, pressure: 150-160 bar, UV-vis detection at $254 \mathrm{~nm}$ ). The retention times of pure $E$-stilbene oxide $\left(10^{-3} \mathrm{M}\right), Z$-stilbene oxide $\left(10^{-3} \mathrm{M}\right)$ and benzaldehyde $\left(10^{-3} \mathrm{M}\right)$ were $6.3,4.9$ and $3.3 \mathrm{~min}$ respectively.

\section{Results and discussion}

The direct oxygen transfer to olefins is a well-known route to obtain epoxides. During the last years, there has been much effort to conduct this transformation selectively under catalytic or electrocatalytic conditions. The pioneering work of Jacobsen-Katsuki reported by Adam et al. [8] for the epoxidation of olefins with a variety of oxidants, provided a remarkably enantioselective method in organic synthesis. Although the synthetic value of this reaction is undisputed, its mechanism still remains a controversy issue. Substrate isomerisation has been of considerable concern in which $Z$ olefins afford a mixture of $E$ and $Z$ epoxides. To explain this loss of stereoselectivity, most often a radical intermediate obtained during the rate determining step has been proposed. This leads to $Z / E$ epoxides through isomerisation by a simple bond rotation (Fig. 3).

In homogenous catalysis, stilbene stereoisomers $(E, Z)$ have been extensively considered as model systems for isomerisation dynamics [9]. Up today, to our knowledge, their epoxidation reaction with molecular oxygen electroassisted by the catalysts structures shown in Fig. 1, has never been undertaken.

\subsection{Electrochemical studies}

In order to ascertain the efficiency of our catalysts, we have put firstly in evidence their electrochemical behaviour by using cyclic voltammetry technique. This measure is necessary to explore the action of the catalysts in inducing the reduction of dioxygen and the electroactivity of the oxo form of the catalysts. The leading idea is the comparison of the electrochemical response of the metal complex alone, in combination with dioxygen, and in combination with dioxygen plus 2-MeI and benzoic anhydride. Since the catalysts present almost a typical electrochemical response, one representative is illustrated in Fig. 4.

Under nitrogen atmosphere a quasi-reversible redox couple is observed at $-0.08 \mathrm{~V}$ for salen, $+0.05 \mathrm{~V}$ for Clsalen (Fig. 4a) and $-0.12 \mathrm{~V}$ for $\mathrm{OCH}_{3}$ salen. The addition of 2-MeI leads to a slight enhancement of the redox system current (Fig. 4b). In the presence of oxygen, the cyclic voltammograms show a remarkable increase of the $\mathrm{Mn}(\mathrm{III}) / \mathrm{Mn}(\mathrm{II})$ reduction peak and a decrease of the corresponding oxidation one.
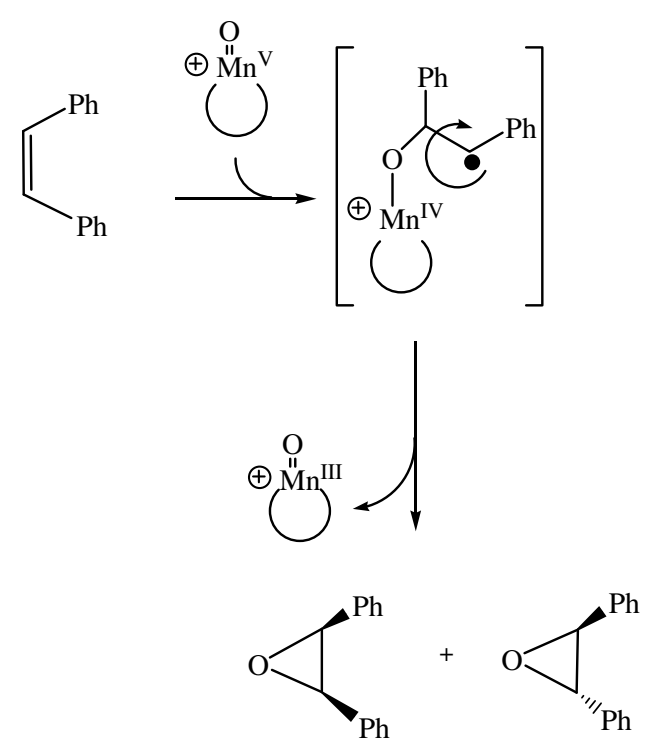

Fig. 3. Mechanism for Mn(III)-salen complexes catalysed epoxidation of olefins. 
a

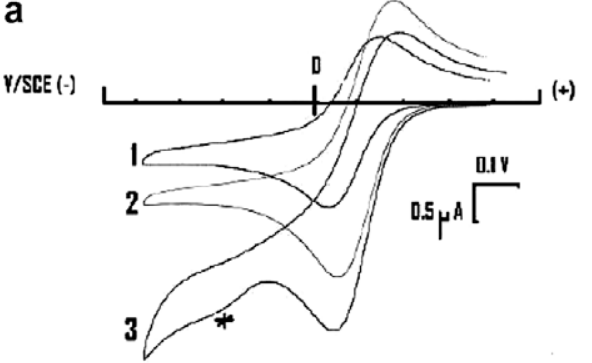

b

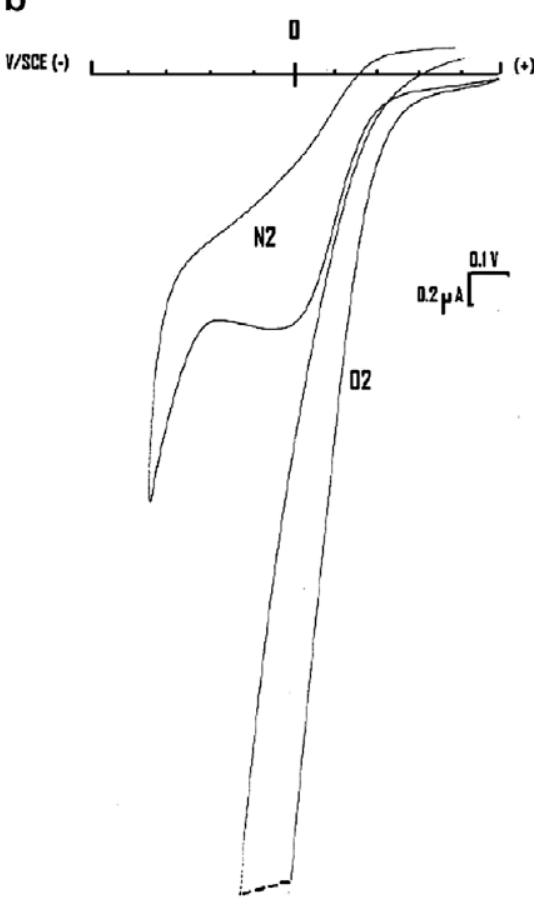

(1) under $\mathrm{N}_{2}$, (2) after addition of 2-MeI Same experimental conditions than in a under $\mathrm{N}_{2}$, (3) same conditions than (2) but with addition of benzoic anhydride. $\mathrm{O}_{2}$ atmosphere

(* dimer $\mu$-oxo)

Fig. 4. Cyclic voltammograms of $\mathrm{Mn}(\mathrm{III})-C l s a l e n$ catalyst, sweep rate: $200 \mathrm{mV} \cdot \mathrm{s}^{-1}$ (E in V versus SCE).

This behaviour is consistent with dioxygen binding to the reduced $\mathrm{Mn}(\mathrm{II})$-salen complex to yield $\mathrm{Mn}(\mathrm{III})$-superoxo-species, which can be reduced by a second electron. The loss of reversibility was assigned to the formation of the active dimer $\mu$-oxo species (marked with * in Fig. 4a) [10]. The addition of benzoic anhydride should lead to a remarkable cathodic current corresponding to the cleavage of the $\mathrm{O}-\mathrm{O}$ bond generating consequently the reactive manganese-oxo species as it was mentioned above.

\subsection{Electrocatalytic epoxidation}

The bulk electrolysis was performed by applying the potential corresponding to the $\mathrm{Mn}(\mathrm{III}) / \mathrm{Mn}(\mathrm{II})$ redox system. The reduction potentials of the redox cationic Mn(III)-salen complex properties depend on the substituents nature. The primarily investigation of the catalytic cycle efficiency described above showed that the epoxidation reaction did not take place in the absence of benzoic anhydride.

It is postulated that the catalytic efficiency for a given catalyst might be appreciated from the ratios of the cathodic peak $\left(i_{\mathrm{pc}}\right)$ currents under oxygen and nitrogen atmosphere $i_{\mathrm{pc}}\left(\mathrm{O}_{2}\right) / i_{\mathrm{pc}}\left(\mathrm{N}_{2}\right)$ [11]. The main results are given in Table 1 .

From the values in Table 2, we point out the following remarks: (i) the $Z / E$ ratios values show clearly that $E$-stilbene is more reactive than its isomer, and the electron releasing substituents slightly enhance the rate of epoxidation. A similar result has been reported by Arasasingham et al. with manganese porphyrins [12]; (ii) the residual benzaldehyde is a persistent by-product; (iii) oxygen atom transfer to E-stilbene occurs with complete stereochemical inversion. Most often, an electrophilic oxo-manganese species attacks the electron-rich double bond, forming a carbon-radical intermediate (Fig. 4) which can explain the (Z/E) isomerisation observed during the epoxidation reaction, since a rotation around the

Table 1

Catalytic efficiency data

\begin{tabular}{llll}
\hline Catalysts & \multicolumn{3}{l}{$i_{\mathrm{pc}}\left(\mathrm{O}_{2}\right) / i_{\mathrm{pc}}\left(\mathrm{N}_{2}\right)$} \\
\cline { 2 - 4 } & $200 \mathrm{mV} / \mathrm{s}$ & $100 \mathrm{mV} / \mathrm{s}$ & $50 \mathrm{mV} / \mathrm{s}$ \\
\hline Salen & 1.57 & 1.66 & 1.68 \\
ClSalen & 1.29 & 1.42 & 1.52 \\
$\mathrm{OCH}_{3}$ Salen & 1.57 & 1.40 & 1.62 \\
\hline
\end{tabular}

Table 2

Bulk electrolysis of stilbene isomers (experiments in $5 \mathrm{~mL} \mathrm{CH}_{3} \mathrm{CN}$, time $20 \mathrm{~min}$ )

\begin{tabular}{|c|c|c|c|}
\hline Catalysts & ClSalen & Salen & $\mathrm{OCH}_{3}$ Salen \\
\hline \multicolumn{4}{|l|}{ With E-stilbene } \\
\hline$E$-stilbene oxide ( $\mu \mathrm{mol})$ & none & none & none \\
\hline$Z$-stilbene oxide $(\mu \mathrm{mol}) /$ Yield $^{\mathrm{a}}(\%)$ & $16.0 / 3.2$ & $18.2 / 3.6$ & $18.5 / 3.7$ \\
\hline Benzaldehyde ( $\mu \mathrm{mol})$ & 13 & 15 & 14 \\
\hline Turnover ${ }^{b}$ & 3.58 & 3.69 & 3.74 \\
\hline Current efficiency ${ }^{c}$ & 80 & 96 & 98 \\
\hline \multicolumn{4}{|l|}{ With Z-stilbene } \\
\hline E-stilbene oxide $(\mu \mathrm{mol}) /$ Yield $(\%)$ & $0.71 / 0.14$ & $1.00 / 0.2$ & $1.00 / 0.2$ \\
\hline$Z$-stilbene oxide $(\mu \mathrm{mol}) /$ Yield $(\%)$ & $29 / 5.8$ & $28 / 5.6$ & $33 / 6.6$ \\
\hline Benzaldehyde ( $\mu \mathrm{mol})$ & 39 & 40 & 43 \\
\hline Turnover & 5.8 & 5.5 & 5.5 \\
\hline$Z / E$ ratio & 40 & 28 & 33 \\
\hline Current efficiency & 55 & 57 & 91 \\
\hline
\end{tabular}

${ }^{a}$ Moles number of epoxide/moles number of olefins.

b Moles number of epoxide/moles number of catalyst.

c Ratio of the electricity consumed by the electrode reaction of interest over the total electricity passed through the circuit, according to [13]. 
formed carbon-carbon single bond is possible if the lifetime of the radical is long enough.

\section{Conclusion}

This study shows the unusual reactivity of Mn(III) tetradentates Schiff bases complexes towards the epoxidation of stilbene isomers. Obviously, the reactions following the rate determining step depends on a number of factors including the oxidation potentials of stilbene isomers, the active oxidant, the steric hindrance, the geometry of the axial ligand, the solvent as well as the tendency of various substrates to undergo rearrangements. A comparison study is now being established by confining the catalysts within organic or inorganic matrix.

\section{References}

[1] F. Bedioui, J. Devynck, C. Bied-Charreton, J. Mol. Catal. A: Chem. 113 (1996) 3.

[2] H. Nishihara, K. Pressprich, R.W. Murray, J.P. Collman, Inorg. Chem. 29 (1990) 1000.

[3] C.P. Horwitz, S.E. Creager, R.W. Murray, Inorg. Chem. 29 (1990) 1006.

[4] K. Srinivasan, P. Michaud, J.K. Kochi, J. Am. Chem. Soc. 108 (1986) 2309

[5] C.P. Horwitz, Y. Ciringh, C. Liu, S. Park, Inorg. Chem. 32 (1993) 5951.

[6] L.J. Boucher, J. Inorg. Nucl. Chem. 36 (1974) 531.

[7] G.C. Salomão, M.H.N. Olsen, V. Drago, C. Fernandes, L. Cardozo Filho, O.A.C. Antunes, Catalysis Commun. 8 (2007) 69.

[8] W. Adam, K.J. Roschmann, C.R. Saha-Moller, D. Seebach, J. Am. Chem. Soc. 124 (2002) 5068.

[9] D.H. Waldeck, Chem. Rev. 91 (1991) 415.

[10] J.-C. Moutet, A. Ourari, Electrochim. Acta 42 (1997) 2525.

[11] P. Guo, K.-Y. Wong, Electrochem. Commun. 1 (1999) 559

[12] R.D. Arasasingham, G.X. He, T.C. Bruice, J. Am. Chem. Soc. 115 (1993) 7985.

[13] Z. Qiang, J.-H. Chang, C.-P. Huang, Water Res. 36 (2002) 85. 